\title{
South African Propaganda Agencies and the Battle for Public Opinion during the Second World War, 1939-1945
}

\author{
Fankie L Monama •
}

\begin{abstract}
South Africa's entry into the Second World War in 1939 was complex. The Smuts government lacked nation-wide support and experienced hostile reactions from opponents of its war policy. It was also subjected to Nazi propaganda offensives, which intensified national divisions and undermined public morale. In response, the Union authorities adopted a volunteer policy for military service and embarked on a massive drive to secure positive public opinion and national support for the war policy. This move led to the establishment of various publicity and propaganda organisations to influence public opinion and to stimulate enthusiasm for the war. However, inadequate policy direction and lacking a solid framework to guide propaganda organisation and operations created inter-agency frictions and rivalries. The study on which this article is based, examined the main propaganda agencies, the Bureau of Information (BOI), the Directorate of Military Intelligence (DMI) and the Union Unity Truth Service (UUTS), which contested one another for jurisdiction, authority and power to shape public opinion in South Africa during the war. The analysis focused on the rationale for their establishment, their purpose, objectives and activities. Then the article reports on the interinstitutional relationships, organisational politics and competition, and how these aspects affected the Union's propaganda enterprise, mobilisation drive and the prosecution of the war effort.
\end{abstract}

Keywords: South Africa, Second World War, Union Defence Force, Bureau of Information, Directorate of Military Intelligence, Union Unity Truth Service, publicity and propaganda

\section{Introduction}

The twentieth century has been dubbed "a century of propaganda". Although this phenomenon is as old as history itself, it was given impetus in the twentieth century by the upsurge of mass communication media, namely radio, films and newspapers. As a vital element in conflict, the value of propaganda was largely demonstrated during the First World War (1914-1918), the first 'total war' in modern history. As Jowett and O'Donnell explain, "no longer did single battles decide wars ... whole nations were pitted against other nations, requiring the cooperation of entire populations, both militarily and psychologically". ${ }^{2}$ To build relations with the home population, governments exploited propaganda to secure positive public opinion and to acquire support for the war policies. ${ }^{3}$ Harold Lasswell, an American social scientist and pioneer of propaganda studies, asserted in 1927 that, "no government could hope to win without a united nation behind it and no government could have a united nation behind it unless it controlled the minds of its people". ${ }^{4}$

Despite being discredited as an "enemy of free thought and speech", and abandoned by major democracies of Great Britain ${ }^{5}$ and the United States of America (USA), ${ }^{6}$ the role of propaganda in future conflicts was still considered necessary. ${ }^{7}$ Adolf Hitler, Nazi leader in Germany, had recognised

- $\quad$ FL Monama (MA, MPhil, PhD) is a senior lecturer in the Department of Military History, Faculty of Military Science, Stellenbosch University (South African Military Academy). 
the significance of propaganda as a 'weapon of war', and took over where the British and the Americans had left off. A special ministry of public enlightenment and propaganda was established in March 1933 under Joseph Goebbels, and waged extensive propaganda campaigns to promote the Nazi ideology in Germany and abroad. ${ }^{8}$ When war erupted in September 1939, many countries rushed to create institutional apparatus for 'information services'. The British, after parliamentary agitations, established the ministry of information (MOI) in September 1939, ${ }^{9}$ and the United States, through the presidential Executive Order 9182 of 13 June 1942, consolidated several heterogeneous and overlapping propaganda agencies to form the office of war information (OWI) ${ }^{10}$ The Union of South Africa (as it was called from 1910-1961) was no exception. At the outbreak of what would become the Second World War (1939-1945), the government established the Bureau of Information (BOI) and other institutions also emerged, to disseminate propaganda and influence public opinion.

South Africa was particularly in a difficult position because its entry into the war lacked nation-wide consensus. The country experienced internal divisions and hostile reactions from sections of the population who objected to intervention in the war. The Union prime minister, General JBM Hertzog, was pro-neutrality and his deputy, General JC Smuts, was pro-intervention in support of Britain. The Union parliament approved Smuts's intervention motion, and Hertzog resigned as prime minister. At the request of Sir Patrick Duncan, the governor-general of the Union, Smuts formed a new government. Hertzog joined the opposition led by Dr DF Malan, an ultra-nationalistic Afrikaner and leader of the National Party. In addition, throughout the 1930s, the Union endured Nazi propaganda offensives, which encouraged exclusive ethnic-nationalism among Afrikaners and promoted the anti-British and anti-Jewish sentiment. ${ }^{11}$ Moreover, the country witnessed a rise of the radical right movements, particularly the pro-Nazi Ossewa-brandwag (OB) (ox wagon sentinels), founded in February 1939. Led by Dr JFJ van Rensburg, the OB embarked on militant campaigns in the country against the Smuts government. ${ }^{12}$ On the other hand, the Union's black society, dissatisfied with the racially induced discriminatory policies against them, displayed ambivalence towards the war and agitated for political concessions. ${ }^{13}$ Consequently, Smuts, confronted with a lack of broader national support, endeavoured to stimulate public enthusiasm in the Union for the war through an organised propaganda drive.

Scholarly literature on South Africa's role and experience during the Second World War is extensive. Besides the official histories, i.e. regimental, operational or military administrative histories,${ }^{14}$ various other publications have focused on South Africa's complex relationship with Great Britain, ${ }^{15}$ while others dealt with the anti-war resistance and organisations, ${ }^{16}$ the social history, adult education as well as the welfare services for white members of the South African military forces. ${ }^{17}$ Yet, unlike in many countries such as Britain, the United States, Germany, Russia and Japan, studies of war propaganda in South Africa are limited. However, there are few publications worth noting, which have endeavoured to provide insight into the subject.

Fransjohan Pretorius produced an excellent work, examining Boer propaganda on commando during the South African War of 1899-1902. It is an important development since most research tends to focus on British propaganda in that war. ${ }^{18}$ With regard to the First World War, some important publications have reflected on propaganda as an element in the broader war theme, but did not provide an in-depth analysis. These are by authors Bill Nasson ${ }^{19}$ and Albert Grundlingh. ${ }^{20}$ In the case of the Second World War, Suryakanthie Chetty has examined the Union government's attempts to foster 'national unity' through visual propaganda, by analysing the pro-war publication, Libertas and the two film documentaries, Fall in and With our men in the North. ${ }^{21}$ However, the focus is slanted towards women and some representations of blacks. Nicole Wiederroth also produced an article on war propaganda, specifically the introduction of radio broadcasting for blacks to combat the perceived 
subversive agitations amongst them. ${ }^{22}$ Research is mainly limited to the objectives of radio services to South African blacks and their reactions. As recent and useful works on the theme of war propaganda in the Union, these publications offer insights into the 'products' of propaganda agencies. Except for Wiederroth, limited attention is given to the organisational dynamics, institutional politics, interagency rivalries and competing agendas in an effort to manipulate public opinion in South Africa.

This article, based chiefly on a study of archival sources, attempts to provide a critical perspective on South Africa's institutional apparatus for war propaganda during the Second World War. For reasons of scope, the study primarily examined three major agencies as lenses through which to view the Union's wartime dynamics of the propaganda system and institutional politics regarding the shaping of public opinion and the implications for the war effort. These are the BOI, the Department of Defence (DOD)'s directorate of military intelligence (DMI) and the Union Unity Truth Service (UUTS). The analysis centred on the organisation and purpose of the propaganda agencies, inter-institutional relationships and the conception of their roles with regard to the shaping of public opinion. The study sought to explore why the Union's wartime propaganda system was described by witnesses as a "chaotic state of affairs", and how this affected the war effort. ${ }^{23}$

\section{From Government Printer to Bureau of Information (BOI)}

Wednesday, 6 September 1939, marked South Africa's official severing of ties with the German Reich and entering the war in support of Britain. ${ }^{24}$ Internal conflict erupted and the country was divided into two major blocs: the pro-neutrality (generally referred to as 'anti-war') and the prointervention (generally referred as 'pro-war') blocs. ${ }^{25}$ Furthermore, the black communities also displayed mixed reactions, from moderate support to apathy or rejection of the war policy. ${ }^{26}$ What is more, there was inadequate policy direction, no immediate defence plans, limited manpower, and a lack of equipment and training facilities. ${ }^{27}$ The Union Defence Force (UDF) also endured internal disaffections as some members objected to the war policy and rejected military service outside South Africa. ${ }^{28}$ To complicate matters, Nazi Germany, in an attempt to limit the war potential of Britain, her main European rival, waged extensive propaganda to foster defeatism and to cultivate the neutrality of enemy countries, including South Africa. ${ }^{29}$

These constraints troubled Smuts with respect to the effective implementation of the war policy. To minimise internal tensions and resentment, Smuts adopted a volunteer policy for military service. This effectively necessitated a massive drive to encourage recruitment to fill the ranks of the UDF. Publicity and propaganda became areas of immediate government activity. However, the government had neither a policy nor a centrally organised publicity and propaganda system to facilitate the mass mobilisation of public support for the war effort. ${ }^{30}$ Pre-war publicity for the government, both statutory and commercial, was handled by the Government Printer, Lieutenant Colonel JJ Kruger, as the director of government printing and stationery services. ${ }^{31}$ Other state departments such as the departments of railways and harbours, education and the post office, had their small publicity units. When hostilities broke out, the government made money available and various state departments "became publicity conscious", resulting in chaotic overlaps and duplication. ${ }^{32}$ Due to the requirements for military service, the Government Printer was faced with staff shortage while there was an increase in the accounts for state recruiting schemes; therefore, publicity was outsourced to private advertising agencies. ${ }^{33}$ Still, the government was confronted with the question of an "efficient dissemination of a multitude of ideas to the mass of the people, in an effort to secure maximum positive results in the various spheres of war activity". ${ }^{34}$ 
On 18 September 1939, Smuts met his interior minister responsible for internal security and propaganda, HG Lawrence, and outlined his objectives. The priority was to counter the Nazi propaganda conducted through the German-based Zeesen radio. ${ }^{35}$ Broadcasting in different languages, including Afrikaans to South Africa, Zeesen radio was exploited by the Nazis since 1933 to conduct propaganda to promote their cause across the world. ${ }^{36}$ Anxious about its effect on the intensification of the opposition against him, Smuts bemoaned the Zeesen propaganda offensives and the agitation of the public. ${ }^{37}$ He suggested 'jamming' the broadcast, but Lawrence felt that such action would risk eliminating the wireless if Germany retaliated. Instead, it was suggested to arrange with the Union's public broadcaster, the South African Broadcasting Corporation (SABC), to allocate at least 30 minutes for the government broadcast to counter the Zeesen. ${ }^{38}$ Already, on 18 September 1939, the SABC board had resolved to support the government's war policy. ${ }^{39}$ The broadcasts were to focus on the government's policy and war position and not on party politics. ${ }^{40}$ Smuts also wanted the establishment of a publicity committee with "at least one first-class journalist" on it. ${ }^{41}$

That journalist was Arthur N Wilson of the Argus Printing and Publishing Company. He became the government information officer in the 'Office of the Prime Minister', to give the public "the right information and guidance". ${ }^{42}$ The post of information officer had existed in the public service department since January 1936 but was never utilised. ${ }^{43}$ In September 1937, the then prime minister, Hertzog, decided to institute a press intelligence office to provide the 'correct information' about government activities to the press, "as the press was most important in the formation of public opinion" ${ }^{44}$ In October 1937, the designation changed to that of information officer. ${ }^{45}$ With the change of government in September 1939, Smuts appointed Wilson to head the official institution called the Bureau of Information (BOI), with the initial mandate of combating Zeesen propaganda. ${ }^{46}$ In August 1940, the BOI was moved to the interior department under HG Lawrence. Wilson was required to provide the war-related news, confidential information to form the background to leading articles and to put out broadcasts every evening at 19:15. He was also required to liaise with the British Ministry of Information (MOI) to determine what kind of information was required about South Africa in relation to the war. ${ }^{47}$

The BOI was established $a b$ initio. From its inception, Wilson and his ten-member staff operated 'haphazardly' without any "set policy or driving purpose". ${ }^{48}$ In November 1939, the BOI defined its objectives and scope in a memorandum submitted to the cabinet sub-committee on publicity:

- The collection and organisation of information related to government policy and activities for purposes of publication;

- The examination of Zeesen broadcasts and the preparation of statements relating thereto for transmission over the radio and to the press;

- The preparation of statements of a more direct propaganda value for radio transmission and publication to the press;

- The liaison with London, arrangement and supply of publicity photographs, weekly press cuttings and news summaries to the British Press Relations Officer. Also, to maintain contact and exchange information with the British High Commissioner in South Africa; and

- The maintenance of friendly contacts with the press and distribution of news to newspaper correspondents, and also to maintain a close watch on the South African press for all comments and news of interest to the Union government. ${ }^{49}$

The BOI, henceforth, superseded the Government Printer as the primary state institution for coordinating publicity and propaganda, linking the government, including the DOD, to the public. ${ }^{50}$ 
The Government Printer would then focus on the UDF's printing and stationery services. ${ }^{51}$ The BOI was required to disseminate propaganda through the newspapers, radio and films to assist the government in popularising its war policy. ${ }^{52}$ For the Union authorities, the main priority was the white Afrikaans-speaking audience in the country. There were fears of the destabilisation effect of Nazi propaganda, which was fostering extremist Afrikaner nationalism, cultivating a pro-Nazi bias and preaching the 'neutrality concept', which was obstructive to recruitment and mobilisation. ${ }^{53}$ Thus, the BOI's main propaganda effort was defined:

To try and convert the [white] Afrikaans-speaking section of the population from their present pro-Nazi attitude of the mind, to a belief in the justice of the Allied cause, and to a subsequent or consequent belief in the correctness of South Africa's policy of entering the war. ${ }^{54}$

Wilson's strategy was to discredit Zeesen by analysing the transcripts from the SABC, then to expose its inaccuracies and factual distortions, and provide 'authentic' information. ${ }^{55}$ As war developed, the activities of the BOI expanded, taking over the 'publicity' role for other state departments and facilitating the production of propaganda films. ${ }^{56}$ Unlike the British MOI or the American OWI, the Union's BOI was not located at the highest echelons of state power, i.e. at ministerial level. ${ }^{57}$ Politically and administratively, the BOI was controlled from the interior minister's office.

Without any official state policy, Wilson operated on an ad hoc basis - using his own "superinitiative and creative impulse", which became "embarrassing to the Civil Service and Treasury". ${ }^{58}$ This produced criticisms and clashes over authority, responsibility and jurisdiction, making it imperative for the authorities to review and reorganise the complete state publicity and propaganda machinery. Therefore, the government introduced the publicity and propaganda advisory committee with the object of assisting and advising the BOI, and with the view to securing better propaganda coordination to "attain definite objectives". ${ }^{9}$

\section{BOI vs DOD: Inter-agency clashes and reorganisation of state publicity and propaganda}

Regarded by the state as an "essential war department ... and the staff doing important war work", 60 the BOI was subjected to severe criticisms for various reasons. Wilson's counter-statements against Zeesen were criticised as unnecessary "childish backchat". ${ }^{61}$ Moreover, the BOI was criticised by the public and the opposition press ${ }^{62}$ for having staff members, including Wilson, who were not fluent in Afrikaans, thus "failing to understand the psychology of the Afrikaans-speaking people". ${ }^{63}$ The appointment of two fully bilingual and well-known journalists, M Uys Krige and SJ Marais Steyn, to the BOI in 1940, was aimed at solving the language deficiency. ${ }^{64}$ The DOD was particularly very critical of the BOI's general conduct and coordination of state publicity and propaganda. ${ }^{65}$ Military officers accused the BOI of monopolising all the news, insufficient coverage of military activities, the lack of quality reporting and administrative inefficiency in relation to disseminating propaganda material to the wider public across the Union. ${ }^{66}$ The stage was set for a long turf war between the BOI and the DOD over authority and control of publicity and propaganda towards the public. The DOD regarded itself as the most qualified state institution for that purpose, and wanted direct control of the propaganda machinery to facilitate the shaping of public opinion. ${ }^{67}$

In November 1939, the DOD appointed a chief press liaison officer, Captain WA Bellwood, on the staff of the secretary for defence, Brigadier General $\mathrm{CH}$ Blaine. ${ }^{68}$ The main objective of the chief press liaison officer was to facilitate the effective coordination of the DOD's recruiting and publicity efforts in a 'centralised' manner via the deputy adjutant general and director of recruiting, Colonel GCG Werdmuller. Bellwood then recommended a publicity scheme, which involved 
broadcasting and producing material for films about servicemen, issuing booklets and brochures, developing posters for recruitment and also informing the public about the defence activities through the press. ${ }^{69}$ This scheme, which clearly reflected similar tasks performed by the BOI, was surprisingly approved by the Union's chief of the general staff (CGS), Major General (later Lieutenant General) Sir Pierre van Ryneveld, and confirmed via a circular instruction in May 1940:

The Chief Press Liaison Officer [Bellwood] ... is the direct representative of the Director General of Operations in regard to all matters concerning the Press and other publicity. No statement for the Press or for any other channel of publicity shall be issued by any Section or by any Command unless it has been approved by the Director General of Operations or his representative above-mentioned. All arrangements in regard to broadcasting and films, shall be made through the Director General of Operations or his representative above-mentioned, and no independent arrangement may be made. ${ }^{70}$

Bellwood's appointment represented a parallel structure competing with the BOI as conduit for propaganda dissemination. Thus, two state institutions were on a collision course. In August 1940, despite Van Ryneveld's approval of the military's publicity scheme, Wilson issued a request to the DOD to have a military officer "with considerable journalistic experience and news sense", representing the BOI in the office of the CGS - the highest military office - for "access to all documents relating to training, operations and manoeuvres" pertaining to the UDF, and to have "absolute right to interview regularly" heads of all sections of the DOD. ${ }^{71}$ This request by Wilson, aimed at propagating the UDF to the public, was also a way of asserting authority. He regarded the BOI as a "propagandist for the Defence Department and the purveyor of information generally". 72 Wilson's conception of his role contrasted with how the DOD authorities perceived themselves and their role in terms of publicity and propaganda.

The heads of sections in the UDF rejected Wilson's request. Brigadier General J MitchellBaker, the quartermaster general, argued that the DOD officers and heads of sections were "overworked and harried" for them to be subjected to regular interviews. ${ }^{73}$ Colonel HT Newman, deputy director of military intelligence (DDMI), also refused. He contended, "it cuts right across the intelligence organisation" of the DOD, which incidentally, already had Major DAW Ruck, a capable officer heading the military publicity section called DMI (Ic), who did not "require journalistic flair", but could efficiently perform the functions "concerned with publicity, propaganda and censorship". ${ }^{74}$ The BOI officials were also accused of having "little military experience or knowledge, and not knowing what they wanted". ${ }^{75}$ It was further argued that the UDF's director general of operations (DGO), Brigadier P de Waal, was responsible for what was released to the press, "not a civilian over whom the Defence Department exercises no control". ${ }^{76}$

Matters came to head in October 1940, during a meeting held by the interior minister, CGS, BOI, the director of military intelligence (DMI) and the director general training and operations (DGT $\& \mathrm{O})$. It was reported that things were not going right in the BOI and that the UDF troops were "getting no useful publicity". The problem was attributed to poor relations between the DMI, the BOI and the press via the South African Press Association (SAPA). Van Ryneveld threatened to "get rid of individuals causing problems or altering the existing organisation". ${ }^{77}$ In that meeting, other DOD officers explicitly stated they wanted to "conduct [their] own publicity and propaganda" and they possessed the required expertise to "run [their] own show". ${ }^{78}$ However, in an apparent volte-face, Van Ryneveld reminded the delegates that the medium for the dissemination of news was the BOI. It was unclear whether he referred to propaganda or 'hard news'. Nobody in that meeting asked for clarity. 
To reduce the constant squabbles, the interior minister requested Wilson to provide a report explaining the purpose and responsibilities of the BOI in order to justify its existence and expenditures. ${ }^{79}$ The report outlined various activities:

- Dissemination of news and publicity on the activities of the DOD;

- Compiling daily press reports for circulation within government to create awareness about the public's criticisms, grievances and political tendencies;

- Handling official press statements from senior government or military officials;

- Coordinating radio broadcasts;

- $\quad$ Facilitating the production and dissemination of propaganda films;

- $\quad$ Serving as the publicity agency for the DOD's director of recruiting (Werdmuller);

- Mediating between the press and military censorship on relevant matters; and

- Coordinating publicity with other state departments. ${ }^{80}$

With regard to the press liaison section of the DOD (Bellwood's section), it was unclear where it was located; however, it was somehow required to operate via the BOI for the dissemination of propaganda about the UDF to the public. ${ }^{81}$ As Van Ryneveld pointed out, the whole system was failing and it produced confusion and duplication. This needed to be altered.

Thus, in December 1940, Lawrence established a six-member national advisory committee on government publicity headed by the pressmen, Sisson Cooper, general manager of the Cape Argus Group, and EB Dawson, then editor of the Sunday Express, as the vice-chairman. ${ }^{82}$ The DOD officers, Brigadier General HJ Lenton (controller of censorship) and Colonel Newman (DDMI) also sat on that committee, which was allocated $£ 47000$ for a propaganda campaign for a period of six months ${ }^{83}$ As an advisory organisation, the committee was required to make recommendations regarding government's publicity and mobilisation effort. ${ }^{84}$ In addition, it could co-opt representatives from the DOD's recruiting and intelligence sections, the controller of manpower and the director general of war supplies (DGS) for the purposes of directing the Union-wide publicity and propaganda drive for the mobilisation of manpower for military service. ${ }^{85}$ It was the first major effort at reorganising the state publicity and propaganda machinery to reduce tensions and to improve coordination.

In December 1940, the advisory committee recommended that Wilson discontinue the broadcast of his lengthy speeches. ${ }^{86}$ Instead, government officials would give talks on their departmental activities, and prominent loyalists in the Union, who were experts in their fields, were invited to talk on the theme, "Why we are in the war", whose aim was to elaborate on South Africa's rationale for participating in the war. ${ }^{87}$ The broadcast schedule with the SABC was changed to 19:45, to elaborate on issues just after the news. These changes came into effect on 6 January $1941{ }^{88}$ Furthermore, the staff of the BOI was expanded and roles were redefined. Piet Beukes and Uys Krige dedicated their efforts to the Afrikaans programmes and Captain Nigel Sutherland, a radio liaison, was attached to the DGS. ${ }^{89}$ These changes brought limited improvements, as the BOI and the DMI (Ic) seemed to have cooperated better for a few months. Still, the lack of a broad propaganda policy remained a problem.

In August 1941, the DMI (Ic) highlighted the need for "a clear lead in POLICY ... or general propaganda framework", because at that time, there were instances of "confused propaganda arising out of the absence of policy". ${ }^{90}$ For example, the government adopted a 'soft approach' on military recruitment to protect domestic labour needs, whilst the DMI (Ic) (via the BOI) had intensified propaganda for military engineers or motor transport. ${ }^{91}$ Such contradictions exposed the weaknesses of the advisory committee, which was supposed to have created institutional harmony in the whole propaganda machinery. The main reason for its weakness was that it was an ad hoc body with limited power - purely advisory in nature and purpose. ${ }^{92}$ 
By mid-1942, the advisory committee was replaced by a military-dominated structure called the defence recruiting and publicity committee, headed by Colonel Werdmuller (director of recruiting) and Dr EG Malherbe (DMI) as the vice-chairman. It had representations from other state departments and the BOI (Wilson). This committee, operating under the secretary for defence (Blaine), had advisory and executive powers; however, due to the perennial manpower problem, its scope was limited to recruiting schemes. ${ }^{93}$ The BOI remained the chief state propaganda agency and the Government Printer was accountable for financial expenditures. ${ }^{94}$ Within the military circles, dissatisfactions regarding the BOI's monopoly of war-related publicity and propaganda towards the public continued to persist.

\section{The AES, ${ }^{95}$ SAPR $^{96}$ and BOI: Intensification of rivalries and the effect on the propaganda effort}

Whilst the BOI focused on stimulating the public for war support, the defence authorities were confronted with disconcerting reports about troop apathy and disloyal tendencies within the UDF. ${ }^{97}$ Those reports, reflecting the political dissensions and growing manifestations of the Nazi-inspired political extremism in the country, produced fears within the military establishment. ${ }^{98}$ The major concerns were the political and military implications for the troops' loyalty and morale. ${ }^{99}$ Consequently, 'constructive propaganda' within the UDF became imperative. The responsibility fell on the DMI to deal with security, intelligence, local censorship and propaganda. ${ }^{100}$ Major Ruck, who became the officer commanding (OC) of the propaganda sub-section of military intelligence, DMI (Ic), had suggested various propaganda initiatives for troops, including lecture services and talks, newspapers, recreation and entertainment services to improve their morale. ${ }^{101}$ Those suggestions were not considered due to concerns about military discipline, ${ }^{102}$ that is, until reports of apathy and disloyalty within the forces alarmed military authorities about the negative effect on troop cohesion. An opportunity was thus presented for the DMI (Ic) to demonstrate its capacity to conduct military propaganda - within the UDF. ${ }^{103}$

While the military authorities were contemplating the introduction of propaganda within the UDF, the interior minister believed that propaganda activities were the concern of the BOI and not the function of the military. ${ }^{104}$ It was only after the submission of a proposal for an educational scheme for the troops by an unofficial committee led by Alfred Hoernlé, an influential professor of philosophy at the University of the Witwatersrand and liberal supporter of Smuts, that action was taken. ${ }^{105}$ The Hoernlé scheme was supplemented by another proposal by Captain (later Major) Leo Marquard, an instructor at the South African Military College, who was supported by Major (Dr) EG Malherbe (later DMI). The Malherbe-Marquard scheme proposed the training of military officers for political education of the troops. It differed from the Hoernlé scheme due to its focus on military officers, not civilians, to conduct such educational services. ${ }^{106}$

The fundamental feature of the two schemes was to develop the consciousness of the UDF troops regarding the reasons for participation in the war, to realise not only what they were fighting against, but also the cause they were fighting for - to preserve the country's political, cultural and economic assets. ${ }^{107}$ With the support of Smuts and Van Ryneveld, an army education services (AES) headed by Dr Malherbe as chief education officer, was instituted in February 1941. The AES was managed through the DMI (officially classified as Im - with $m$ for morale). ${ }^{108}$ The Hoernle scheme was instituted in the active citizen force (ACF) by a panel of civilian lecturers. ${ }^{109}$ It was a major institutional response by the Union government and military authorities to wrestle with the question of disaffections and morale within the UDF. It was essentially what the officers in the DMI (Ic) have 
been advocating for. ${ }^{110}$ The question of the role of the AES and its operational scope requires further clarification.

The AES served to cultivate troop consciousness about the Union's assets for preservation, to strengthen their morale and to "improve the fighting force against Nazism". ${ }^{111}$ The intended goals were "to equip soldiers to defend democracy and to equip citizen-soldiers to build a better democracy once the threat of Fascism has been removed". ${ }^{112}$ The four-week AES instructional course, which began in March 1941, with 38 carefully selected UDF members, took place at the South African Military College, Voortrekkerhoogte (formerly Roberts Heights), in Pretoria. ${ }^{113}$ Presented by various experts in their fields, the AES curriculum included topics such as the cultural-political and internal military relations among troops, economic production and income distribution, comparative political and economic systems, social interactions and race relations, psychological features of propaganda, historical and ideological aspects of the war. ${ }^{114}$ After completion of the course, the graduates, then called information officers (IOs), were distributed among the UDF units to commence with their 'political education' work. The DMI (Ic), in terms of propaganda within the UDF, could then exhibit its creativity in support of the AES programme. Headed by Captain RN Lindsay and Lieutenant J Malherbe (Dr EG Malherbe's wife), the main tasks of the DMI (Ic) included the handling of censorship among troops, publicity of military activities and public relations (for the UDF) in the Union and in the field. ${ }^{115}$ Although the focus of the DMI (Ic) was supposed to be within the UDF (except for censorship), evidently, its 'public relations' activities competed with those of the BOI.

The official state agency for propaganda towards the public was the BOI, liaising with the DMI (Ic) for military security and censorship issues. ${ }^{116}$ However, unofficially, the DMI (Ic) conducted 'public relations' by directly contacting newspapers for publication of military-related material which the press were eager to do. ${ }^{117}$ Circumventing the official government propaganda institution was an affront on the authority of the BOI. The DMI (Ic) indicted the BOI on its ineffectiveness, for example, delays in informing the press timeously regarding military manoeuvres, using articles produced by the DMI (Ic) for broadcasts instead of handing them to the newspapers, disregarding newspaper edition deadlines by late submission of material and generally, despite various overtures from the Ic, the director (Wilson) being uncooperative. ${ }^{118}$

In addition, when the AES was instituted, it immediately collaborated with the UDF's Film Unit, led by Major HC Weaver, for training the IOs in the use of projectors, and for production and circulation of instructional and propaganda films. ${ }^{119}$ Wilson did not approve of such a film unit and protested that it "would encroach on his preserves". ${ }^{120}$ In this case, he was referring to the film trade in which the BOI had contracted the well-known African Films (later Metro-Goldwin-Mayer [MGM] and Twentieth Century Fox - which were all foreign companies) for processing and distribution of propaganda films. A South African company, Union Films Ltd, was not considered for film production and, upon follow-up inquiries, Wilson indicated that it was an unknown entity. Ironically, Union Films was the only company to have sent their own cameraman to East Africa to produce UDF newsreels which, incidentally, were used by African Mirror (an African Films branch), supplied via the BOI. ${ }^{121}$ This provided more grounds for criticism by the DMI (Ic) of the BOI for having unwarranted monopoly to the detriment of qualitative and expeditious propaganda efforts. The AES did not cooperate with the BOI because, ironically, the troops "were apt to discount the Bureau as a propaganda machine and, therefore, distrust it". ${ }^{122}$ Yet, they relied on the AES.

In his reaction to criticism, Wilson produced reports about the activities of the BOI for Smuts and Lawrence, and later forwarded copies to the DMI for their own analysis. He emphasised the reasons for the existence of the BOI, and listed various activities ranging from news services for local and foreign papers, broadcasting and film work to DOD support and miscellaneous services. ${ }^{123} \mathrm{He}$ 
previously also asked for support to reorganise and expand his limited staff (of 45 by 1941), which was "overworked" due to the "multiplication of duties in several cases impairing efficiency". ${ }^{24}$ Apparently, the BOI was overstretched due to the high demand for propaganda, especially with the escalation of the anti-government militancy and subversive activities in the country. ${ }^{125}$ As such, Wilson lamented 'unwarranted' criticisms against his institution and requested protection from government because, with a limited staff, he was "doing all that could be done in the sphere of propaganda and publicity". ${ }^{126}$ To promote the UDF's war effort further and to ensure wider publicity in the Union and abroad, the BOI had requested the DOD to assist in providing facilities for its war correspondents in the field. This resulted in yet another organisation being established for that purpose, the South African Public Relations (SAPR) unit, operating in Egypt from October 1941. ${ }^{127}$

The SAPR was intended to arrange facilities such as camp, transport, censorship and transmission facilities for the war correspondents to obtain news, photographs and films "before and during active operations" for publicity purposes. ${ }^{128}$ For control purposes, the unit fell under the command of the general officer administration (GOA), UDF Middle East Force, Major General FH Theron. The SAPR's officer commanding, initially referred to as the chief press liaison officer and later called assistant director public relations (ADPR), was Lieutenant Colonel EP Hartshorn, who was then succeeded by Major RN Lindsay in 1944. The SAPR also had its own Radio Observer unit and the Film and Photographic unit. ${ }^{129}$ It soon ran into problems with the BOI. Its officers, taking advantage of their access to battlefield information, argued that they were better equipped and competent enough to carry out propaganda activities. The BOI was an unnecessary and redundant organisation. ${ }^{130}$ Conflict between the BOI and SAPR then ensued.

In April 1944, Lieutenant Colonel DH Ollemans, a UDF chief press officer, produced a report regarding the SAPR set-up in the North. In his report, the BOI was dismissed as a "non-military organisation" incapable of providing the necessary military background information required for publicity. ${ }^{131}$ Theron had made a similar observation the previous year, and requested that the military undertake its own propaganda activities or exercise closer control over the BOI. ${ }^{132}$ Wilson objected to such requests and reminded the critics that it was his prerogative to "supervise, control and coordinate the conduct of propaganda in the Union and outside". ${ }^{133}$ The BOI was also providing service to the troops by editing and managing the military newspapers, EAForce News and Springbok, thus helping the AES. ${ }^{134}$ Wilson further rejected the suggestion by the newspaper editors for a press officer to be appointed in the office of Van Ryneveld to obtain direct military information. He contended that a press officer in Defence Headquarters (DHQ), working independently of the BOI, would be regarded as a public snub. ${ }^{135}$

In one form or another, three state organisations, the AES (DMI, Ic), SAPR and the BOI, performed 'independent' propaganda functions in an effort to influence public opinion. Their intermittent conflict over the monopoly of propaganda operations led to overlaps, inefficiency, delays and sporadic delivery of 'information services' to the public. This resulted in low civilian and military morale, low recruitment figures and national complacency. ${ }^{136}$ At the end of 1943, the Government Printer and his officers concluded that propaganda efforts were failing due to the "disorganised nature of [the] State publicity machine". ${ }^{137}$ "Evidence of failure," they pointed out, "can be observed in the current disconcerting apathy which permeates the people as a whole". ${ }^{138}$ However, there were other factors such as war-weariness, socio-economic factors and the absence of any direct military threat due to the remoteness of the country from the war zone. ${ }^{139}$ However, emphasis was on the lack of centralised coordination in the propaganda system and organisational deficiencies to an extent that state departments would work at cross-purposes, e.g. recruiting whilst demobilising. The Government Printer emphasised the need for a central coordinating structure with executive powers to "create 
order out of the existing chaos ... where nearly every government department or section [was] endeavouring to conduct its own publicity and propaganda". ${ }^{140}$

It was also difficult for the government authorities to manage the inter-institutional rivalries politically. Each of those organisations had justifiable reasons for its existence. The DMI/AES preserved military morale, with a broad vision of a liberal post-war social order; the BOI sustained civilian morale, while also assisting with military recruitment. They all enjoyed the support of Smuts and Van Ryneveld. The problem was their indifferent relations and persistent clashes. However, the interior minister, Lawrence, often prevailed politically in support of Wilson because he "rendered good services to the State in most difficult times". ${ }^{141}$ Therefore, the BOI retained a prominent position as the main state propagandist.

\section{The Union Unity Truth Service: Non-state propaganda movement}

Propaganda in South Africa was not limited to state institutions. Loyal members of the Smuts government, concerned about the rise of opposition to the Union's war policy and the development of the Nazi-inspired political extremism, reacted by establishing the Union Unity Truth Service (UUTS). This movement, created in September 1939, was inspired by Sir James Rose Innes, Brigadier General HNW Botha, Colonel Sir W Dalrymple and Sir Charles Smith. These prominent supporters of Smuts publicly appealed for "a large fighting publicity fund to finance a nation-wide campaign to support Government ... to deal with propaganda from abroad and misrepresentations at home ... to promote mutual understanding between all sections of people". ${ }^{142}$ Therefore, the UUTS was created to carry out the objectives of the Union Unity Fund. ${ }^{143}$ The goal of the movement was to provide intellectual, moral and political support for Smuts and the national government in the prosecution of the war. ${ }^{144}$ The South African public was implored to contribute financially and pledge their support for the objectives of the UUTS - "to help in the effort of counter-propaganda". ${ }^{145}$

The UUTS operated from Johannesburg, and presented itself as 'the new Crusade', with Smuts as its commander-in-chief. Upon its establishment, Thomas C Robertson, a journalist working as a parliamentary correspondent for the Rand Daily Mail, became its director. ${ }^{146}$ The UUTS also had its own propaganda advisory committee under the chairmanship of Senator G Hartog (a member of parliament). To pursue its objectives, the movement adopted Afrikaans and English as the language policy, ${ }^{147}$ and advocated a militant propaganda carried out by an organisation independent of government. ${ }^{148}$

The UUTS, in apparent contrast with the BOI, resolved to operate independently to conduct "aggressive and partisan propaganda" which would not commit government. ${ }^{149}$ Nevertheless, the relations between the BOI and the UUTS soon became strained. The UUTS was not a state institution. Its propaganda - or what was proffered as counter-propaganda activities - was funded by contributions from private citizens and the proceeds from sales of Smuts's speeches, booklets and badges. ${ }^{150}$ It was linked to government through the advisory committee chaired by the ruling United Party (UP) member of parliament (MP) (Senator Hartog). ${ }^{151}$ The UUTS's field unit, called the Truth Legion, consisted of loyalists who supported the Smuts government and were recruited as active canvassers and propagandists for the movement. ${ }^{152}$ This 'independent' movement organised various pro-war propaganda schemes, such as the production of Afrikaans-language films, for example Noordwaarts (Northwards), the publication of an illustrated magazine called Libertas, and also organised publicity campaigns such as 'Peace through victory', to counter the anti-intervention elements advocating peace with Germany. ${ }^{153}$ In addition, the UUTS operated a clandestine radio 
broadcast called 'Mystery Radio Freedom', which criticised the opponents of the Union's war policy and attacked the Zeesen broadcasts. ${ }^{154}$

Apparently, Wilson perceived the activities of the UUTS as intruding on his domain, and he adopted a competitive attitude. For example, Robertson (UUTS director) threatened inter-agency 'war' when Wilson's film advisory committee recommended the distribution of an Afrikaans newsreel produced by UUTS cameraman, Leon Schauder, 'free of charge', to a mobile advertising agency, Parker's Talkie Tours, to show to the Afrikaner nationalist communities of the countryside. "Serious competition had now arisen," protested Robertson, because the UUTS also relied on the revenue generated from their Afrikaans film tours to the Afrikaans audience. ${ }^{155}$ Again, after Japan's entry into the war against the Allies, the UUTS suggested anti-Japanese propaganda; ${ }^{156}$ however, Wilson rejected it. He reasoned that the 'whole' of UUTS's effort is counter-propaganda against the "Nazi menace" (only against Germany), and therefore it must not deviate from that mission. ${ }^{157}$

After the creation of the UUTS, the short-lived national advisory committee on government propaganda resolved in October 1940 that the BOI and the UUTS be naturally divided and that they should perform independent functions, with the former working for the state. ${ }^{158}$ Due to the absence of a central legal structure with executive powers or a broad policy framework for systematic coordination of propaganda activities, rivalries, overlaps and clashes ensued. ${ }^{159}$ Instead, collaboration was more favourable between the DMI (Ic) and the UUTS. ${ }^{160}$ Ostensibly irritated by the lack of cooperation from Wilson, the DMI (Ic) ventured to suggest that the BOI should be absorbed by the UUTS as it was an unaffordable "extravagance" to have both in the country. ${ }^{161}$

The relationship between the DMI (Ic) and the UUTS was strengthened further through joint educational collaboration. In December 1940, the UUTS established a School of Propaganda and Political Education, operating from the Kero Hotel, Johannesburg. ${ }^{162}$ This School delivered a ten-day propaganda course to a specially selected group of young South Africans from mainly white universities, through a series of lectures by expert individuals, government officials and academics. The lecturers included Advocate G Saron (Nazism and the Fifth Column), Professor Leo Fouché (propaganda history), Dr Malherbe (film propaganda), and others such as Professor Hoernlé, Professor T Haarhoff, Professor ID MacCrone and Dr S Biesheuvel, who formed part of the military's education programme, the AES. ${ }^{163}$ The UUTS also brought in the head of the Bantu Press, BFG Paver, whose company was tasked to produce propaganda newspapers for blacks. ${ }^{164}$ In some instances, the UUTS liaised with OWI (United States) and MOI (Britain) for supplying propaganda material from those countries for distribution in South Africa. The activities of the Truth Legion were also extended to other parts of Africa to generate "sympathisers" to the Allied cause, particularly in Portuguese East Africa. ${ }^{165}$

The existence of the UUTS clearly challenged the position of the BOI. Most of its activities overlapped with those of the BOI, with sporadic collaboration. ${ }^{166}$ It was even remarked, during the course of the war, that the UUTS appeared to be undertaking tasks which were rightly within the scope of the BOI. ${ }^{167}$ There was a concerted effort by the UUTS to be inclusive and to cooperate with other organisations to eliminate inter-agency frictions. However, it was a non-state organ and its limitation was that it essentially supported the ruling UP. Its members also campaigned for the government during the 1943 elections. ${ }^{168}$ Such a position also drew public criticism and mistrust. ${ }^{169}$

The interior minister was once again at pains to deal with the inter-agency quarrels involving the UUTS. An informal and unofficial four-member structure called the coordinating committee (representing the BOI, the DMI, the UUTS and the UP), chaired by Dr Malherbe, was attempted in 1942, to facilitate smooth co-operation between the different propaganda agencies. ${ }^{170}$ However, it had no legal standing or powers to enforce decisions. It mainly offered suggestions and recommendations 
as a "coordinating body of government publicity". ${ }^{171}$ Despite the existence of such a structure, where the meeting of interests and mutual understanding could be facilitated between the main propaganda organisations, a cooperative spirit remained elusive. During 1944-1945, there was mounting criticism levelled against the BOI as a "weak link"172 and a gatekeeper ${ }^{173}$ and it was even accused of "inefficiency or deliberate devilry" for allowing unedited items for publication by the newspapers. ${ }^{174}$ However, the controlling influence of Wilson and the reluctance of Smuts and Lawrence to oppose him ensured that the BOI retained its eminent position as the main institution for state propaganda. Many of its detractors, though, wished that the BOI "should disappear". ${ }^{175}$

\section{Concluding perspectives}

When war broke out in September 1939, government and public opinion was divided. Undercurrents of apathy, hostile reactions and limited enthusiasm, which emanated from the prevailing political, social, cultural and racial tensions and differences in society, alarmed Union authorities about the effect of the potential fissures on the effective implementation of the war policy. This necessitated the creation on an information agency responsible for the interpretation of government's policy and war position to the public, in order to secure national support and to sustain morale. The BOI was then established as an official agency to engage in the government's publicity and propaganda efforts during the war. Apart from the initial mandate to combat Nazi propaganda directed at South Africa, the brief and scope of the BOI were not defined. There was no well-thought-out government strategy, policy or broad frame of reference on which to base the activities of the BOI.

This lack of clarity created problems with regard to the objectives, operational scope and limits of the BOI. Wilson, who then defined the scope, believed that the BOI was the sole agency to preserve public morale and the main conduit for the dissemination of government propaganda in all matters pertaining to the war. To him, all other organisations existed to provide support for the BOI. This view was incompatible with other propaganda institutions. The Government Printer and the DMI were concerned about the subordination of the national propaganda operations to a single agency. The UUTS, a pro-war but non-state propaganda organisation, also encountered problems with the BOI. The most persistent problem related to the monopolisation of propaganda by one institution, the BOI, which also attempted to determine the priorities and objectives of other organs - the DMI for UDF morale, and the UUTS for countering the Nazi menace. These agencies contended that the BOI did not have sufficient capacity in terms of manpower, resources and technical capabilities for such a huge national undertaking. This resulted increasingly in competitive behaviours of the different propaganda institutions and produced overlaps, duplication, confusion and rivalries, which then affected the effectiveness of the whole propaganda system.

It is harder to establish whether the conflicting relations between the different propaganda agencies had any significant negative effect on the war effort. However, it could be inferred from the reports that, as the war progressed and the demands of the war increased, the task of government became harder, particularly with regard to maintaining sufficient troop levels and sustaining morale. The office of the Government Printer explained that the weaknesses in the existing propaganda practices were the "spasmodic schemes":

Between each scheme there is a lull, frequently of several months, during which no attempt is made to sustain public interest. The public mind consequently goes to sleep, and each new scheme has an unnecessary burden placed upon it, in as much that it has virtually to start from scratch. ${ }^{176}$ 
Although this report appeared in 1943, other reports generated within government structures reiterated similar deficiencies and failures. ${ }^{177}$ The dissemination of propaganda to the broader public was generally weak. The recruiting director, Werdmuller, bluntly dismissed propaganda efforts through radio broadcast as "close to zero". ${ }^{178}$ The resultant widespread apathy, national complacency, low recruitment numbers and deterioration of national morale were reflections of propaganda failure. The problem was attributed to the lack of policy framework and the absence of a central coordinating body with legal powers to direct policy and action; hence, a chaotic state of affairs. This affected government's ability to articulate a precise vision around which the Union population, with divergent interests and aspirations, could unite as a national body. However, it would be simplistic to attribute propaganda failure to inter-agency rivalries or a lack of policy thereof. Other factors were at play.

After almost five years of war, people's priorities had shifted. Most people were contemplating the post-war social and economic conditions. As one officer noted, people were "concerned about the satisfactory economic basis for living". The prevailing apathy was caused by the fact that "no man [was] certain whether he should defend his country or himself". ${ }^{179}$ Propaganda efforts could also not overcome the existing divisive barriers such as racial policies, political loyalties and contradictory nationalistic identities, which had become entrenched in the social structure of the South African society.

Although there was no collapse of the war effort, endeavours to achieve national war cohesion and unity were undermined by the persistent inter-agency rivalries and turf wars. This was a result of the absence of clear foundations as well as the unplanned and unsystematic propaganda organisation. However, the value of having an efficient propaganda institution to influence public opinion and to promote state policies was realised. By mid-1944, the BOI was transformed from a wartime measure to a permanent state publicity institution beyond the war. A State Publicity Office was recommended. ${ }^{180}$ To "avoid disorganisation and overlapping and unnecessary expense", a central control measure was also recommended. ${ }^{181}$ At the end of 1944, the government approved the State Publicity Office accountable to the Central Control Committee with executive powers, to "guide and direct the general policy of the organisation". ${ }^{182}$ This illustrated that at the outbreak of the war, the government had given little thought to the publicity and propaganda system. Autonomous publicity and propaganda institutions acting 'independently' caused confusion and proved inefficient at lifting national morale. Attempts at improving the system, however, were too little too late. The National Party seized the opportunity of population apathy and low morale brought about by the war conditions to gain support and secure electoral victory at the expense of the ruling UP in 1948.

$1 \quad$ J Wilke (ed.) "Introduction". In Propaganda in the $20^{\text {th }}$ century: Contributions to its history. (New Jersey, NJ: Hampton Press, 1998, 1; GS Jowett \& V O’Donnell. Propaganda and Persuasion, $4^{\text {th }}$ ed. London \& New Dehli: Thousand Oaks, 2006. 201.

Jowett \& O’Donnell op. cit., 207.

Ibid., 205-206; TH Qualter. Propaganda and Psychological Warfare. New York, NY: Random House, 1962. 6; S Rogerson. Propaganda in the next war. London: Geoffrey Bless, 1938. 1; M Howard, "Total war in the $20^{\text {th }}$ century: Participation and consensus in the Second World War". In B Bond \& I Roy (eds). War and society: A yearbook of military history. New York, NY: Holmes and Meier, 1975, 216; M Balfour. Propaganda in war: 1939-1945: Organisation, politics and publics in Britain and Germany. London: Routledge, 1979, 437.

4 HD Lasswell. Propaganda technique in the world war. New York, NY: Peter Smith, 1938 (first published in 1927), 10.

5 C Larson. "The British Ministry of Information”. The Public Opinion Quarterly 5/3. 1941. 412-431; T Willcox. "Projection or publicity? Rival concepts in the pre-war planning of the British Ministry of Information". Journal of Contemporary History 18/1. 1983. 97-116.

6 GE McMillan. "Government publicity and the impact of war". The Public Opinion Quarterly 5/3. 1941. 383-398. 
Rogerson op. cit., 1; Lasswell op. cit., 15; A Rhodes. Propaganda: The art of persuasion: World War II. London: Angus and Robertson, 1976, 107; Jowett \& O’Donnell op. cit., 208-217; Qualter op. cit., 66.

Larson op. cit., 412; Wilke op. cit., 1-2; Qualter op. cit., 112-114; Balfour op. cit., 422-425; Howard op. cit., 218; Jowett \& O'Donnell op. cit., 212.

$9 \quad$ Larson op. cit., 413; Willcox op. cit., 98-99.

10 Those agencies were the Office of Government Reports (July 1939), the Division of Information of the Office of Emergency Management (March 1941) and the Office of Facts and Figures (October 1941). See South African National Defence Force Archives (SANDFA), Union War Histories (UWH), Box 273, B.I. 25, Co-ordination of Wartime Propaganda in the United States of America, by HBD Blauvelt, Representative of US Office of War Information (OWI) to the Union Unity Truth Service (UUTS) Propaganda Advisory Committee, n.d.; see also C Larson. "The domestic motion picture work of the Office of War Information". Hollywood Quarterly 3/4. Summer 1948. 434-443; McMillan op. cit., 391-393; S Weinberg. "What to tell America: The writers' quarrel in the Office of War Information". The Journal of American History 55/1. June 1968; DH Culbert (ed). Information control and propaganda, Part I, The Director's central files, 1942-1945. Maryland, MD: University Publications of America, 1986, xv-xiii; CR Koppes \& GD Black. "Blacks, loyalty, and motion: Picture propaganda in World War II". The Journal of American History 73/2. 1986. 383-406.

C Marx. "'Dear listeners in South Africa': German propaganda broadcasts to South Africa". South African Historical Journal 27. November 1992. 148-172; A Hagemann. "Very special relations: The 'Third Reich' and the Union of South Africa, 1933-1939". South African Historical Journal 27. November 1992. 137-138; M Shain. "Anti-Semitism and South African society: Reappraising the 1930s and 1940s". South African Historical Journal 27. November 1992. 186-197; K Fedorowich. "German espionage and British counter-intelligence in South Africa and Mozambique, 1939-1944". The Historical Journal 48/1. 2005. 209-230; PJ Furlong. "Allies at war? Britain and the 'Southern African Front' in the Second World War". South African Historical Journal 54/1. 16-29; PJ Furlong. Between crown and swastika: The impact of the radical right on the Afrikaner Nationalist Movement in the fascist era. Johannesburg: Wits University Press, 1991; R Citino. Germany and the Union of South Africa in the Nazi period. New York, NY: Greenwood Press, 1991.

For details on the Ossewa-brandwag activities during wartime, see GC Visser. OB: Traitors or Patriots?. Johannesburg: Macmillan, 1976; C Marx. The Oxwagon Sentinel: Radical Afrikaner Nationalism and the history of the Ossewabrandwag. Pretoria: University of South Africa Press, 2008; Furlong, Between crown and swastika ... op. cit.

T Karis \& GM Carter (eds). From protest to challenge: A documentary history of African politics in South Africa, 1882-1964, Vol. 2: Hope and challenge, 1935-1952. Stanford, CA: Hoover Institution Press, 1973, 339-340; see also LWF Grundlingh. "The participation of the South African blacks in the Second World War". Unpublished D. Litt et Phil thesis, RAU, Johannesburg, 1986. IJ van der Waag. "Contested histories: Official history and the South African Military in the twentieth century". In J Grey (ed.), The Last Word? Essays on Official History in the United States and British Commonwealth. Westport, C: Praeger 2003, 27-52. See also the recently published centenary commemorative work titled "The South African Armed Forces, 1912-2012". Scientia Militaria, 40/3, 2012.

R Hyam \& P Henshaw. The Lion and the Springbok: Britain and South Africa since the Boer War. Cambridge: Cambridge University Press, 2003; A Jackson. The British Empire and the Second World. London: Hambledon Continuum, 2006; A Stewart. Empire Lost: Britain, the Dominions and the Second World War. London: Continuum, 2008; Furlong, "Allies at War? ..." op. cit., pp. 16-29. Furlong, Between Crown and Swastika ... op. cit.; Visser op. cit; Citino op. cit.; C Marx, The Oxwagon Sentinel ... op. cit.

N Roos. Ordinary Springboks: White Servicemen and Social Justice in South Africa, 1939-1961. Aldershot: Ashgate, 2005; M Cardo. “'Fighting a Worst Imperialism”: White South African Loyalism and the Army Education Services (AES) during the Second World War". South African Historical Journal, 46/1. May 2002. 141-174; H Bantjés. "Die Vermaaklikheidsgroep van die UnieVerdedigingsmag Gedurende die Tweede Wêreldoorlog: 'n Historiese Ontleding". Unpublished MA thesis, University of Pretoria, Pretoria, 1990; IJ van der Waag. A History of the South African Defence Force Institute (SADFI), 1914-1990. Pretoria: 1 Military Printing Unit, SADF, 1991. and Commonwealth History, 37/3. September 2009. 399-419. 
19 B Nasson. "War Opinion in South Africa, 1914". The Journal of Imperial and Commonwealth History, 23/2. 2005. 248-276; B Nasson. World War One and the People of South Africa. Cape Town:

Tafelberg, 2014.

Troops in the First World War, 1914-1918. Stellenbosch: Sun Press, 2014.

S Chetty. "Imagining National Unity: South African Propaganda Efforts during the Second World War". Kronos 38/1. 2012. 106-130.

N Wiederroth. "Radio broadcasting for blacks during the Second World War: 'It could be dangerous ...". Historia 57/2. November 2012. 104-149.

National Archives of South Africa, Pretoria (hereafter NASAP), Department of Trade and Industry Archives (HEN), Box 2191, 432/1/13, Vol. 2, Memorandum on government publicity and propaganda by Maj. PT van der Walt and Sergeant VJ Clapham, 27 November 1943.

Union of South Africa. "Proclamation no. 197 of 1939". Union Government Gazette Extraordinary 117/1344. 6 September 1939.

SANDFA, UWH, Box 265, B.I. 20, Internal Security, Intelligence summaries, 21 September 1940. The use of the terms 'pro-neutrality' and 'pro-intervention' is an attempt to signify the point that public opinion in South Africa was divided in terms of participation in the war. However, the records simply use the term 'anti-war', which actually implies 'against the war'. It does not seem to have been the case because war had broken out in Europe - the decisive question was whether to intervene or to remain neutral.

See LWF Grundlingh, "The participation of the South African blacks ..." op. cit.; I Gleeson. The Unknown Force: Black, Indian, Coloured soldiers through the two wars. Rivonia: Ashanti, 1994; M Roth. "'If you give us rights we will fight': Black involvement in the Second World War". South Africa Historical Journal 15. November 1983. 85-104.

NASAP, Jan Smuts papers, A1, Vol. 132, Statement of local military position of $7^{\text {th }}$ September 1939, and steps taken thereafter, September 1939; SANDFA, Archives of the Chief of General Staff (CGS) (War), Box 42, 10/4, The Birth of South Africa's Army, 1939/40, 6 September 1940; see also IJ van der Waag, "The Union Defence Force between the two world wars". Scientia Militaria 30/2. 2000. 183-219; N Orpen. East African and Abyssinian campaigns: South African Forces World War II, Vol. 1. Cape Town: Purnell, 1968; HJ Martin \& N Orpen. South Africa at war: South African Forces World War II, Military and industrial organization, 1939-45, Vol. 7. Cape Town: Purnell, 1979. NASAP, Smuts papers, A1, Vol. 132, Col Bartie Thwaites to Lt Gen. Andries Brink, 17 November 1939; NASAP, Smuts papers, A1, Vol. 132, Memorandum, Security of own forces, n.d.; NASAP, Archives of the Department of Justice (JUS), Box 1506, 1/62/39, European War, 1939. Defence Rifle Association, Confidential report of the Magistrate, JG de Vries, 10 October 1939; see also SANDFA, UWH, Box 265, B.I. 20, Internal security, Intelligence summaries, 17 November 1939. See University of Cape Town (UCT) Jagger Library, Archives and Manuscripts, HG (Harry) Lawrence papers, BC640, E.5, Official White Book on Nazi and Nazi propaganda in South Africa, vols 1-5, 1945; University of KwaZulu-Natal (UKZN), Killie Campbell Archives and Manuscripts (KCM), Durban, File 443/1, KCM 56975 (6b), Summary of the Dürckheim report. Plot to annex Union revealed, n.d.; Marx, “"Dear listeners ..." op. cit. 148-172; Hagemann op. cit., 137-138; OV Strahl. Seven years as a Nazi Consul. Cape Town: Ridout, 1942.

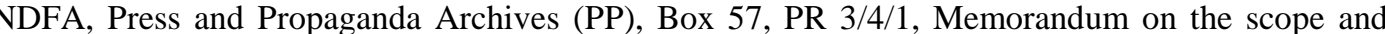
work of the Propaganda Branch of Military Intelligence, 6 August 1940; SANDFA, PP, Box 40, PR 1/2/2, Memorandum for Colonel Campbell-Ross, 24 July 1944.

NASAP, Department of Interior Archives (BNS), Box 317, 317/73, Government publicity and propaganda, by Lt Col JJ Kruger to the Chairman of Committee on Government Publicity and Propaganda (JH de Wet), 1 July 1944. (The original memorandum by Maj. PT van der Walt and Sgt VJ Clapham, regarding the deficiencies of state publicity and propaganda, was produced on 18 November 1943 and submitted to various government departments by Lt Col Kruger on 27 November 1943.) This memorandum is also contained in the NASAP, HEN, Box 2191, 432/1/13, Vol. 2, Memorandum on government publicity and propaganda, 27 November 1943. NASAP, BNS, Box 317, 315/73, Report of the Committee on State Publicity, April 1944, 1-31.

NASAP, HEN, Box 2191, 432/1/13, Vol. 2, Memorandum on government publicity and propaganda, 27 November 1943; NASAP, BNS, Box 317, 317/73, Government publicity and propaganda, 1 July 1944; "Editorial review, Defence Headquarters". The Nongqai. March 1940; “The UDF Map Printing and Printing Company: An exclusive interview with the Assistant Director of Printing and Stationery Services, Major WA Ueckermann”. The Nongqai. August 1942. 
34 NASAP, HEN, Box 2191, 432/1/13, vol. 2, Memorandum on government publicity and propaganda, 27 November 1943. UCT, Lawrence papers, BC640, E3.2, Notes on matters discussed with Smuts, 10:20 to 11:00 am, 18 September 1939. See SANDFA, Archives of Zeesen broadcasts (hereafter ZB), WR 65/9/41-WR 65/9/43, Broadcasts from Enemy Radio Station, 1941-1945; SANDFA, Press and Propaganda Archives (PP), vols 1-31, Zeesen broadcasts, 1940-1945; Marx, “"Dear listeners ...” op. cit., 148-172.

UCT, Lawrence papers, BC640, E3.2, Notes on matters discussed with Smuts, 10:20 to 11:00 am, 18 September 1939; SANDFA, UWH, Box 239, B.I. 1, Extracts of Zeesen broadcasts, SeptemberNovember 1939. For further details, see Zeesen Broadcasts Archives, 1941-1945 and the Press and Propaganda Archives, Zeesen radio broadcasts, vols 1-31, 1940-1945. Most of the extracts covering 1939 come from the Union's intelligence summaries; see also Marx, “"Dear listeners ..." op. cit., 148172.

UCT, Lawrence papers, BC640, E3.2, Notes on matters discussed with Smuts, 10:20 to 11:00 am, 18 September 1939. South African Broadcasting Corporation (SABC), Annual report, 1937-1939, Board's War Policy, 1939, SABC Library, Johannesburg, 4. UCT, Lawrence papers, BC640, E3.2, Notes on matters discussed with Smuts, 10:20 to 11:00 am, 18 September 1939; see also SABC, Annual reports, 1937-1949, Board's War Policy, 1939, 3-4. The policy of the SABC did not support party politics.

UCT, Lawrence papers, BC640, E3.2, Notes on matters discussed with Smuts, 10:20 to 11:00 am, 18 September 1939.

NASAP, Archives of the Social Welfare Department (VWN), Box 940, 278/1, Vol. 2, Appointment of Information Officer, 3 October 1939.

See T Gutsche. The History and Social Significance of Motion Pictures in South Africa, 1895-1940. Cape Town: Howard Timmins, 1972, 370. Officer on the staff of the Prime Minister, 30 September 1937; NASAP, VWN, Box 940, 278/1, Vol. 2, Press Intelligence Officer, Circular to all heads of departments, 30 September 1937. NASAP, VWN, Box 940, 278/1, Vol. 2, Draft instructions on creation of the Information Office in the Department of the Prime Minister, 24 November 1937. NASAP, VWN, Box 940, 278/1, Vol. 2, Appointment of Information Officer, 3 October 1939; UCT, Lawrence papers, BC640, E3.4, Notes of the second meeting of Cabinet Committee on Publicity, 5 October 1939; Union of South Africa, Debates of the House of Assembly, Vol. 40, August-September 1940, col. 1247. UCT, Lawrence papers, BC640, E3.4, Notes of the second meeting of Cabinet Committee on Publicity, 5 October 1939. NASAP, Smuts papers, A1, Vol. 132, Memorandum for Cabinet Sub-Committee on Publicity, 8 November 1939.

Ibid.

See NASAP, Smuts papers, A1, Vol. 144, Memorandum on the Bureau of Information: Present activities, 23 August 1940; NASAP, BNS, Box 317, 315/73, Report of the Committee of State Publicity, 24 April 1944; Union of South Africa, Debates of the House of Assembly, vol. 40, AugustSeptember 1940, col. 1247; NASAP, Smuts papers, A1, Vol. 150, Bureau of Information: Statement on Activities, 21 May 1942. NASAP, BNS, Box 317, 317/73, Government publicity and propaganda, Government Printer's report to the Committee on Government Publicity and Propaganda, 1 July 1944; see also "The UDF Map Printing and Printing Company ..." op. cit.

NASAP, Smuts papers, A1, Vol. 150, Bureau of Information: Statement on activities, 21 May 1942; "The South African Bureau of Information, Interview with the Director, Arthur Wilson". The Nongqai. June 1942.

SANDFA, UWH, Box 239, B.I. 1, Extracts of Zeesen broadcasts, September to November 1939; SANDFA, UWH, Box 281, B.I. 31, Axis broadcasts by traitors, 30 October 1939; NASAP, Smuts papers, A1, Vol. 132, Memorandum, security of own forces, n.d.; NASAP, Smuts papers, A1, Vol. 132, Memorandum for Cabinet Sub-Committee on Publicity, 8 November 1939; UCT, Lawrence papers, BC 640, E3. 183, Memorandum on internal security, 30 May 1940.

NASAP, Smuts papers, A1, Vol. 132, Memorandum for Cabinet Sub-Committee on Publicity, 8 November 1939; NASAP, Smuts papers, A1, Vol. 144, Memorandum on the Bureau of Information: Present activities, 23 August 1940. 
NASAP, Smuts papers, A1, Vol. 132, Memorandum for Cabinet Sub-Committee on Publicity, 8 November 1939.

NASAP, Smuts papers, A1, Vol. 144, Memorandum on the Bureau of Information: Present activities, 23 August 1940; Union of South Africa, Debates of the House of Assembly, 24 August to 14 September 1940, vol. 40, col. 1247; "The South African Bureau of Information ..." op. cit.; NASAP, BNS, Box 317, 317/73, Government publicity and propaganda, Government Printer's report to the Committee on Government Publicity and Propaganda, 1 July 1944. Larson, "The British Ministry of Information" op. cit., 412-431; Willcox op. cit., pp. 97-116; Culbert op. cit., xv-xiii; Koppes \& Black op. cit., 383-406. NASAP, BNS, Box 317, 315/73, Report of the Committee on State Publicity, April 1944, 5. UKZN, Malherbe papers, File 438/1, KCM 56974 (531b), Memorandum on state publicity, n.d.; NASAP, HEN, Box 2191, 432/1/13, Vol. 2, Memorandum on government publicity and propaganda, 27 November 1943; see also J Mervis. The Fourth Estate: A Newspaper Story. Johannesburg: Jonathan Ball, 1989, 224-242. See comments by the Bureau of Information's wartime staff member, KG Dimbleby. Hostilities Only. Cape Town: Unie-Volkspers, 1944, 16-17. Mostly it was Die Vaderland, Die Transvaler, Die Burger and Die Volksblad, see SANDFA, UWH, Box 265, B.I. 20, Intelligence summaries, 10 November 1939; SANDFA, UWH, Box 265, B.I. 20 , Intelligence summaries, 17 November 1939.

SANDFA, UWH, Box 265, B.I. 20, Intelligence summaries, 10 November 1939; SANDFA, UWH, Box 265, B.I. 20, Intelligence summaries, 17 November 1939; NASAP, Smuts papers, A1, Vol. 142, Memorandum on the duties of Information Officers, Wilson to the Prime Minister (Smuts), 14 February 1940; FD Tothill. "The 1943 General Election". Unpublished MA thesis, University of South Africa, Pretoria, 1987, 109-111.

SANDFA, PP, Box 63, PU 6/9/1, Bureau of Information: Memorandum to the South African press, 1 August 1940; Union of South Africa, Debates of the House of Assembly, vol. 40, August-September 1940, col. 1247; Tothill op. cit., 114; SANDFA, PP, Box 63, PU 6/16, Bureau of Information Reorganisation, Wilson to Kreft, 14 July 1941.

SANDFA, CGS (War), Box 197, 42/4, Press Liaison Officer, Thwaites to Blaine, 13 November 1939.

Ibid.; SANDFA, CGS (War), Box 197, 42/4, Reply of the UDF Quartermaster General (QM) and the Director General Operations (DGO) to the Director of Information, 28 August 1940; SANDFA, CGS (War), Box 197, 42/4, Minutes of a meeting on the working of the existing organisation for press information, publicity and propaganda, 17 October 1940. Further details on the criticism of BOI during the war related to the delays of information required by the rural-based newspapers for publication, reported by Lt (later Capt.) Janie Malherbe of UDF Military Intelligence, see UKZN, Malherbe papers, File 143/2, KCM 56992 (15b), Memorandum concerning the Bureau of Information, Captain (Mrs) Janie Malherbe, 16 March 1942.

SANDFA, CGS (War), Box 197, 42/4, Minutes of a meeting on the working of the existing organisation for press information, publicity and propaganda, 17 October 1940; SANDFA, PP, Box 63, PU 6/9/4, Report of meeting of Newspaper Editors Consultative Committee, 23 October 1940.

SANDFA, CGS (War), Box 197, 42/4, Instructions governing publicity, 11 November 1939.

SANDFA, CGS (War), Box 197, 42/4, Memorandum on the plan for Press and Information Division, 3 April 1940; SANDFA, PP, Box 39, PR 1/5, Organisation of propaganda projects, Kreft to S Cooper (of The Star newspaper and head of government consultative committee on publicity and propaganda), 13 June 1941.

SANDFA, CGS (War), Box 197, 42/4, CGS Minute 46/A, 6 April 1940; SANDFA, CGS (War), Box 197, 42/4, Circular to all heads of sections and OCs commands, 24 May 1940.

SANDFA, CGS (War), Box 197, 42/4, Wilson to Van Ryneveld, 16 August 1940.

Ibid.

SANDFA, CGS (War), Box 197, 42/4, Mitchell-Baker (QMG) to Van Ryneveld (CGS), 28 August

SANDFA, CGS (War), Box 197, 42/4, Director General of Operations (DGO) (signed by HT Newman and endorsed by Quartermaster-General, Brig. Gen. J. Mitchell-Baker) to Chief of the General Staff (CGS), Van Ryneveld, 28 August 1940.

\section{SANDFA, CGS (War), Box 197, 42/4, DGO to CGS, 28 August 1940.}

Ibid.

SANDFA, CGS (War), Box 197, 42/4, Minutes of a meeting on the working of the existing organisation for press information, publicity and propaganda, 17 October 1940. 
Ibid.

NASAP, Smuts papers, A1, Vol. 144, Memorandum on the Bureau of Information: Present activities, 23 August 1940; Union of South Africa, Debates of the House of Assembly, 24 August to 14 September 1940, vol. 40, col. 1247.

NASAP, Smuts papers, A1, Vol. 144, Memorandum on the Bureau of Information: Present activities, 23 August 1940; "The South African Bureau of Information ..." op. cit.

Union of South Africa, Debates of the House of Assembly, vol. 40, August-September 1940, col. 1247; SANDFA, PP, Box 63, PU/6/3, Report on relationship between the Bureau of Information and Military Intelligence, DMI (Ic) to DDMI, 8 January 1941; see also SANDFA, CGS (War), Box 197, $42 / 4$, Report on the control of military information issued to the public through the press, newsreels, broadcasts, etc., DDMI's Reply to Controller of Censorship, 16 April 1942.

English-language newspaper companies played a critical role in supporting the Union's war policy by seconding members to serve on government publicity institutions, by publicising UDF military activities and also by engaging in counter-propaganda efforts against the opposition press and the Zeesen propaganda. See Dimbleby op. cit., 16-17; Mervis op. cit., 224-242.

SANDFA, Archives of Adjutant General, Group 3 (AG3), Box 6, Notes on meeting of Defence Authorities Committee, 23 December 1940-24 January 1941; SANDFA, CGS (War), Box 197, 42/4, Lawrence to Blaine, 22 December 1941; NASAP, HEN, Box 2191, 432/1/13, Vol. 2, Memorandum on government publicity and propaganda, 27 November 1943.

UCT, Lawrence papers, BC 640, E3. 58, National Advisory Committee on Publicity, 6 January 1941; SANDFA, CGS (War), Box 43, 10/7, Deputy Director of Recruiting to the Defence Authorities Committee, 3 January 1941.

SANDFA, CGS (War), Box 197, 42/4, Lawrence to Blaine, 22 December 1941.

SANDFA, PP, Box 63, PU 6/3, Complaints: Bureau of Information, 22 August 1940-7 January 1941 (Hand-written) Notes by DDMI (Col Kreft), 23 December 1940.

UCT, Lawrence papers, BC640, E3.58, Report of the National Publicity Committee on Publicity, S Cooper to Lawrence, 6 January 1941; UKZN, Malherbe papers, File 438/1, KCM 56974 (531b), Memorandum on state publicity, n.d.; SABC, Annual report, 1940, 12; SANDFA, UWH, Box 273, B.I. 25, Broadcast by 'panel speakers', 21 June 1941. Among the speakers were academics and government experts in other fields. Academic departments included French Studies, Geology, African Studies, Psychology, Social Science, Commerce, Music, Law, Zoology, History, Fine Arts, Geography and Agricultural Science.

UCT, Lawrence papers, BC640, E3.58, Report of the National Publicity Committee on Publicity, S Cooper to Lawrence, 6 January 1941; SANDFA, UWH, Box 91, MS 71, Radio broadcasting, Wilson to Collyer, 11 January 1941; SANDFA, UWH, Box 91, MS 71, Radio broadcasting, Beukes to Collyer, 30 April 1941.

SANDFA, PP, Box 63, PU 6/16, Reorganisation of Bureau of Information, 14 July 1941.

See PP, Box 57, PR 3/1, Points to be considered in any reorganisation of propaganda, Ic to DDMI, 4 August 1941.

Ibid.

SANDFA, CGS (War), Box 197, 42/4, Lawrence to Blaine, 22 December 1941; NASAP, HEN, Box 2191, 432/1/13, Vol. 2, Memorandum on government publicity and propaganda, 27 November 1943.

NASAP, HEN 2191, 432/1/13, Vol. 2, Memorandum on government publicity and propaganda, 27 November 1943.

Ibid., NASAP, BNS, Box 317, 315/73, Report of the Committee of State Publicity, April 1944.

Army Education Services established in 1941.

South African Public Relations established in 1941.

NASAP, Smuts papers, A1, Vol. 132, Memorandum, Security of own forces, n.d.; SANDFA, CGS (War), Box 197, file 42/2, Extracts and intercepts, foreign papers and broadcasts, 27 September 1940; UKZN, Malherbe papers, File 444/7, KCM 56975 (89), Subversive activities in the Union, Obstructing the war effort, JA Malherbe (Ic), 4 June 1941; UKZN, Malherbe papers, File 444/7, KCM 56975 (87100), Secret Military Intelligence reports on the Ossewabrandwag, c1940-5.

UKZN, Malherbe papers, File 444/7, KCM 56975 (89), Subversive activities in the Union, Obstructing the war effort, J.A. Malherbe (Ic), 4 June 1941; UCT, Lawrence papers, BC640, E5. 45, Nazi activities in the Union of South Africa before and during the war, December 1945; SANDFA, UWH, Box 265, B.I. 20, Secret internal security, Weekly intelligence reports, 1939-1940.

SANDFA, UWH, Box 265, B.I. 20, Internal security, Intelligence summaries, 16 December 1939; SANDFA, UWH, Box 265, Intelligence summary, 5 January 1940; UKZN, Malherbe papers, File 
444/7, KCM 56975 (89), Subversive activities in the Union, Obstructing the war effort, J.A. Malherbe (Ic), 4 June 1941. SANDFA, UWH, Box 86, MS 2, Organisation-Defence Headquarters, Maj. Gen. P. van Ryneveld to heads of sections, 8 February 1940.

SANDFA, PP, Box 39, PR 1/5/2, Propaganda among our troops, G.S.O.2 (Ic) to DGO (for DDMI), 8 November 1940.

SANDFA, AG (3) Box 207, 154/51/50/5, Provision of educational services to the troops, Director General of Training and Operations to the Adjutant General, 27 February 1941; UCT, Jagger Library, Archives and manuscripts, Leo Marquard papers, BC 587, D3.38, History of Army education services, 30 September 1945.

'Military propaganda' was the term generally used to refer to publicity and propaganda activities of the AES towards the Union forces during the war. See SANDFA, World War 2 Diaries (WD), Box 296, Military propaganda handbook No. 1, General Staff Defence Headquarters, Government Printer, Pretoria, 10 January 1941.

SANDFA, PP, Box 63, PU 6/3, Army publicity and propaganda, DMI (Ic) to DDMI, 27 November

UCT, Marquard papers, BC 587, D3.38, History of Army education services, 30 September 1945; for details about Prof. Hoernlé, see W. Sweet. "R.F.A. Hoernlé and idealist liberalism in South Africa". South African Journal of Philosophy 29/2. 2010. pp. 178-194; JH Hofmeyr. "R.F. Alfred Hoernlé: A tribute". Common Sense. August 1943. pp. 12-13; AH Murray. "Thinker and fighter: A memoir". Common Sense. August 1943. pp. 13-14.

UCT, Marquard papers, BC 587, D3.38, History of Army education services, 30 September 1945; Roos op. cit., pp. 48-54; Cardo op. cit., pp. 141-174.

UCT, Marquard papers, BC 587, D3.38, History of Army education services, 30 September 1945; EG Malherbe. Never a dull moment. Cape Town: Howard Timmins, 1981. 215; Roos op. cit., 48-54; Cardo op. cit., $141-174$.

The DMI (Im) was merely a classification in the records. The AES was the main UDF propaganda structure and the DMI (Ic) provided administrative support.

SANDFA, AG (3) Box 207, 154/51/50/5, Establishment S.A. Educational Corps, DGTO to AG, 10 February 1941; SANDFA, AG (3) Box 207, 154/51/50/5, AES approval letter, CGS to DGTO, 17 February 1941; UCT, Marquard papers, BC 587, D3.38, History of Army education services, 30 September 1945; UKZN, Malherbe papers, File 432/1, KCM 56974 (11-14), Recruitment, identification and discharge record relating to Dr EGMalherbe, Volunteer's Identity Book for use on discharge. Dr Malherbe was appointed the Director of Military Intelligence (DMI) in June 1942, and was also in charge of the AES.

See SANDFA, PP, Box 57, PR 3/4/1, Memorandum on the scope and work of the propaganda branch of Military Intelligence, 6 August 1940; SANDFA, PP, Box 39, PR 1/5/2, Propaganda among our troops, G.S.O.2 (Ic) to DGO (for DDMI), 8 November 1940.

UCT, Marquard papers, BC 587, D3.2, Memorandum on educating the troops in the political, social and economic reasons for our being at war (a suggested scheme), 31 October 1940; SANDFA, UWH, Box 287, B.I. 36, The Army Education Scheme for the UDF, Bulletin, 1941, 1-4; Union of South Africa, Department of Defence. Military propaganda handbook No. 1. Pretoria: Government Printer, January 1941, 1-14.

UCT, Marquard papers, BC 587, D3.2, Memorandum on educating the troops in the political, social and economic reasons for our being at war (a suggested scheme), 31 October 1940, 3.

SANDFA, WD, Vol. 1, Box 292, 194/3, The training and work of Education Officers, Broadcast talk by Maj. EG Malherbe, 14 June 1941; UCT, Marquard papers, BC 587, D3.38, History of Army education services, 30 September 1945, 3; Cardo op. cit., p. 15; Malherbe op. cit., 215-217.

UCT, Marquard papers, BC 587, D3.38, History of Army education services, 30 September 1945, Appendix D, Information Officer Course; SANDFA, UWH, Box 287, B.I. 36, The Army Education Scheme for the UDF, Bulletin, 1941, 1-4; SANDFA, AG (3) Box 207, 154/51/50/5, S.A.I.C: Educational Course (784 G), 18 March 1941-18 April 1941, South African Military College, 18 March 1941; Cardo op. cit., 151-154.

SANDFA, CGS (War), Box 197, 42/4, Report on the control of Military Information issues to the public through the press, newsreels, broadcasts, etc., DDMI's reply to Controller of Censorship, 16 April 1942; UKZN, Malherbe papers, File 144, KCM, 56949 (110), Propaganda duties carried out by Capt. (Mrs) Malherbe of Ic Sub-section, DDMI, 30 September 1942; SANDFA, AG (War), Box 4, 168/2/2/2, Reorganisation of Director of Military Operations and Intelligence, 13 July 1943. 
SANDFA, CGS (War), Box 197, 42/4, Interior Minister (Lawrence) to Secretary for Defence (Blaine), 22 December 1941; NASAP, Smuts papers, A1, Vol. 150, Bureau of Information: Statement on activities, 21 May 1942.

See SANDFA, PP, Box 63, PU 6/6, Report of meeting of Newspaper Editors Consultative Committee, 23 October 1940; UKZN, Malherbe papers, File 144, KCM, 56949 (110), Propaganda duties carried out by Capt. (Mrs) Malherbe of Ic Sub-section, DDMI, 30 September 1942.

SANDFA, PP, Box 63, PU 6/3, Report on the relations between the Bureau of Information and Military Intelligence, Appendix A, Instances in which the Bureau has failed Ic, 13 January 1941; UKZN, Malherbe papers, File 143/2, KCM 56992 (15b), Memorandum concerning the Bureau of Information, by Captain (Mrs) Janie Malherbe, 16 March 1942.

UCT, Marquard papers, BC 587, D3.38, History of Army education services, 30 September 1945, 24; see also NASAP, BNS, Box 317, 317/73, Government Printer's report to the Committee on Government Publicity and Propaganda, 1 July 1944.

SANDFA, PP, Box 63, 6/9/5, Précis of discussion with Mr AN Wilson, DMI (Ic) to DDMI, 6 January

SANDFA, PP, Box 63, PU 6/3, Bureau of Information and Union Films - Summary of correspondence, 11 January 1941.

UCT, Marquard papers, BC 587, D3.38, History of Army education services, 30 September 1945, Relations with other organisations, 22-26.

See NASAP, Smuts papers, A1, Vol. 150, Bureau of Information: Statement on activities, 21 May 1942; similar copy in SANDFA, PP, Box 63, PU 6/16, Statement on activities, Wilson to Col J Kreft, dated 13 May 1942.

SANDFA, PP, Box 63, PU 6/16, Bureau of Information: Reorganisation proposal, Wilson to Lawrence, 14 July 1941.

For details on subversive activities, see Visser op. cit.; Furlong, Between Crown and Swastika ... op. cit.; Marx, The Oxwagon Sentinel ... op. cit.

SANDFA, PP, Box 63, PU 6/9/1, Bureau of Information: Establishment and organisation, 14 July

SANDFA, UWH, Box 162, Narep Unfo 16, Cursory survey of the activities of the South African public relations, Compiled for historical records and war diary, Cairo, 30 November 1944.

SANDFA, CGS (War), Box 197, 42/4, Louis Esselen to Van Ryneveld, 16 October 1941.

SANDFA, UWH, Box 162, Narep Unfo 16, Cursory survey of the activities of the South African public relations, Compiled for historical records and war diary, Cairo, 30 November 1944.

SANDFA, PP, Box 63, PU 6/9/4, Report on military publicity and propaganda by Assistant Director of Public Relations, General Officer Administration, UDF Middle East Force, 22 February 1944.

SANDFA, UWH, Box 162, Narep Unfo 16, South African public relations, Annexure A, Memorandum of SA news coverage to GOA by Lt Col DH Ollemans, 10 April 1944.

SANDFA, CGS (War), Box 197, 42/3, Theron to Van Ryneveld, 16 April 1943.

SANDFA, CGS (War), Box 197, 42/3, Director of Information's reply to General Theron, Wilson to Theron, 11 May 1943.

Ibid.; UWH, Box 162, Narep Unfo 16, Cursory survey of the activities of the South African public relations, Compiled for historical records and war diary, Cairo, 30 November 1944.

SANDFA, CGS (War), Box 197, 42/4, Thwaites to Van Ryneveld, 11 December 1943; SANDFA, CGS (War), Box 197, 42/4, AA Frew to Campbell-Ross, 7 February 1944.

SANDFA, Army Intelligence, Box 46, CE 2/15, Low level of morale on the home front, 24 February 1942; UKZN, Malherbe papers, File 441/10, KCM 56974 (864), Army morale and propaganda, by DMI (Ic), March 1943; SANDFA, Quartermaster General (QMG), Group 1, Box 104, Q 91/339, Morale in the Army, 25 August 1943; NASAP, HEN, Box 2191, 432/1/13, Vol. 2, Memorandum on government publicity and propaganda, 27 November 1943; Martin \& Orpen op. cit., 104-106, 159.

NASAP, HEN, Box 2191, 432/1/13, Vol. 2, Memorandum on government publicity and propaganda, 27 November 1943.

Ibid.

See SANDFA, Quartermaster General (QMG), Group 1, Box 104, Q 91/339, Morale in the Army, 25 August 1943.

NASAP, BNS, Box 317, 317/73, Government Printer's report to the Committee on Government Publicity and Propaganda, Annexure A.

SANDFA, CGS (War), Box 197, 42/4, Campbell-Ross to GB Dawson, 17 February 1944.

University of the Witwatersrand (Wits), William Cullen Library, Archives and manuscripts, Union Unity Truth Service and Truth Legion (UUTS), A 1883, 1, Union Unity Truth Service and Truth 
Legion: Truth Legion Constitution, Unity Fund, n.d.; see also "A call for Union Unity for Freedom, Truth and Democracy". Rand Daily Mail. 14 October 1939.

Wits, UUTS, A 1883, 1, Union Unity Truth Service, n.d.; see also Suggested scheme of organisation for propaganda to be known as "Union Unity Truth Service", October 1939.

Wits, UUTS, A 1883, 1, Truth Legion Constitution, n.d.

UCT, Lawrence papers, BC640, E3.7, Address by General Rt. Hon. JC Smuts on the Union Unity Fund, Cape Town, 9 February 1940.

Wits, TC Robertson papers, A 2012, B20.2, Minutes of the Propaganda Advisory Committee of the Union Unity Truth Service, 9 August 1940.

Wits, UUTS, A 1883, 1, Language Policy of the Union Unity Truth Service, 14 August 1940.

Wits, Robertson papers, A 2012, B20.2, Minutes of the Propaganda Advisory Committee of the Union Unity Truth Service, 14 October 1940.

Wits, Robertson papers, A 2012, B20.2, Co-ordination of propaganda in the Union, Results of the deputation to the Minister of Interior, Minutes of the Propaganda Advisory Committee of the Union Unity Truth Service, 12 February 1942.

See NASAP, Smuts papers, Vol. A1, 303/1, General Smuts's speech at Bloemfontein, 3 November 1939. This speech was translated and published by TC Robertson, Director of the Union Unity Truth Service.

UCT, Lawrence papers, BC640, E3.6, What is the Union Unity Fund?, Circular, 9 February 1940; Wits, Robertson papers, A 2012, B20.2, Minutes of the Propaganda Advisory Committee of the Union Unity Service, 18 December 1941.

Wits, UUTS, A 1883, 1, Truth Legion Constitution, Unity Fund, n.d.

UUTS, A1883, 3, Torch Sparks, A pamphlet for communicating UUTS information to officials and members, Issue no. 5-7, 1940-1941.

Wits, Robertson papers, A 2012, Ae 5.1, Broadcasting, October to November 1941.

Wits, Robertson papers, A 2012, B20.2, Minutes of the Propaganda Advisory Committee of the Union Unity Truth Service, 12 February 1942.

See discussions on Japan's entry into the war, Wits, Robertson papers, A 2012, B20.2, Minutes of the Propaganda Advisory Committee of the Union Unity Service, 18 December 1941.

Wits, Robertson papers, A 2012, B20.2, Minutes of the Propaganda Advisory Committee of the Union Unity Truth Service, 12 February 1942.

Wits, Robertson papers, A 2012, B20.2, Co-ordination of propaganda in the Union, Results of the deputation to the Minister of Interior, Minutes of the Propaganda Advisory Committee of the Union Unity Truth Service, 12 February 1942.

The National Advisory Committee on Government Publicity and Propaganda was ineffective because it was purely advisory with no legal powers to enforce decisions. The UUTS deputation also highlighted the same problem as the reason for clashes.

Wits, Robertson papers, A 2012, B20.2, Co-ordination of propaganda in the Union, Results of the deputation to the Minister of Interior, Minutes of the Propaganda Advisory Committee of the Union Unity Truth Service, 12 February 1942.

SANDFA, PP, Box 63, PU 6/3, Report on the relations between the Bureau of Information and Military Intelligence, 13 January 1941.

Wits, UUTS, A1883, 14, Course in propaganda, Modern propaganda scheme for training of frontline workers, School of Propaganda and Political Education, 10 December 1940.

SANDFA, UWH, Box 287, B.I. 36, The Army education scheme for the UDF, Bulletin, 1941, 1-4; SANDFA, AG (3) Box 207, 154/51/50/5, S.A.I.C.: Educational Course (784 G), 18 March 1941-18 April 1941, South African Military College, 18 March 1941; Wits, UUTS, A1883, 14, Programme and lectures for the School of Propaganda and Political Education, 9 December 1940; Malherbe op. cit., 218; Cardo op. cit., 151-154.

For history of black newspapers, see T Couzens. "History of Black Press in South Africa, 1836-1960". Additional seminar paper, no. A 15, Institute for Advanced Social Research, University of the Witwatersrand, 1984, 24-26; Robertson papers, B20.2, Minutes of the Propaganda Advisory Committee of the Union Unity Truth Service, 9 August 1940. Wits, UUTS, A1883, 20, Union Unity Truth Service, Annual report, November 1943.

See NASAP, BNS, Box 317, 315/73, Report of the Committee on State Publicity, 1-31, Appendix II, Achievements of the Bureau of Information, October 1939-February 1944, April 1944, 1-7; Compare with activities of UUTS, A1883, 20, Union Unity Truth Service, Annual Report, November 1943. 
Wits, Robertson papers, A 2012, B20.2, Co-ordination of propaganda in the Union, Results of the deputation to the Minister of Interior, Minutes of the Propaganda Advisory Committee of the Union Unity Truth Service, 12 February 1942.

The UUTS produced posters, stamp stickers, cartoons, magazines, brochures, photographs of UP leaders, bulletins, newspaper advertisements, films and loudspeaker announcements, in service of the United Party, University of South Africa (Unisa), Archives and Manuscripts Library, South African United National Party (UP) Archives, Central Head Office, General Elections 1943, Correspondence and propaganda, May-July 1943; see also Tothill op. cit., 239-245.

Wits, UUTS, A1883, 20, Union Unity Truth Service, Annual Report, November 1943.

Wits, Robertson papers, A 2012, B20.2, Minutes of the Propaganda Advisory Committee of the Union Unity Truth Service: Memorandum: Co-ordination of existing propaganda activities in the Union, 12 February 1942.

UKZN, Malherbe papers, File 438/1, KCM 56974 (547), Special meeting of Propaganda Coordinating Committee with the Ministers of Interior and Welfare and Demobilisation, 9 January 1944.

UKZN, Malherbe papers, File 438/1, KCM 56974 (553), Malherbe's letters to Louis Esselen, 16 October 1944, and also to Deputy Chief of Staff, Brig. Gen. HS Wakefield, 17 October 1944.

NASAP, BNS, Box 317, 315/73, Report of the Committee on State Publicity, Appendix II, Achievements of the Bureau of Information, October 1939-February 1944, April 1944.

SANDFA, CGS (War), Box 198, 42/5, Wilson's reply to General Theron's complaint, 3 July 1945.

NASAP, BNS, Box 317, 315/73, Report of the Committee on State Publicity, Appendix II, Achievements of the Bureau of Information, October 1939-February 1944, April 1944, $28-29$.

NASAP, HEN, Box 2191, 432/1/13, Vol. 2, Memorandum on government publicity and propaganda, 27 November 1943.

UKZN, Malherbe papers, File 441/10, KCM 56974 (864), Army morale and propaganda, by DMI (Ic), March 1943; SANDFA, Quartermaster General (QMG), Group 1, Box 104, Q 91/339, Morale in the Army, 25 August 1943; SANDFA, PP, Box 63, PU 6/9/4, Final military publicity campaign, 14 January 1944; NASAP, BNS, Box 317, 315/73, Report of the Committee on State Publicity, April 1944; NASAP, BNS, Box 317, 317/73, Government Printer's report to the Committee on Government Publicity and Propaganda, Annexure A, 1 July 1944; Martin \& Orpen op. cit., 104-106, 159.

SANDFA, CGS (W), Box 197, 42/1, Radio in relation to Military propaganda, Werdmuller to Wakefield, 21 April 1944.

SANDFA, PP, Box 63, PU 6/9/4, Final Military publicity campaign, 14 January 1944.

Union of South Africa, Report of the Inter-Departmental Committee appointed to consider reports of the Committee on state publicity and the Film Committee and other relevant matters, Pretoria, 19 December 1944. According to the report, many witnesses did support the Bureau of Information as a post-war institution and suggested a small central State Publicity Office in the office of the Interior Minister. See also "Information Bureau will be reduced to Publicity Office". The Rand Daily Mail. 13 August 1945.

NASAP, BNS, Box 317, 315/73, Report of the Committee on State Publicity, April 1944, 6-8.

Union of South Africa, Report of the Inter-Departmental Committee appointed to consider reports of the Committee on state publicity and the Film Committee and other relevant matters, Pretoria, 19 December 1944; NASAP, BNS, Box 317, 317/73, CF Clarkson to Owen Grant, 4 October 1945; "Information Bureau will be reduced to Publicity Office". The Rand Daily Mail. 13 August 1945. 